\begin{tabular}{|c|c|c|}
\hline Beitr. Ent. & Keltern & ISSN 0005-805X \\
\hline $\mathbf{5 9}(2009) 1$ & S. $3-18$ & 15.07 .2009 \\
\hline
\end{tabular}

\title{
In Memoriam: Donald Burton Baker (1922-2004)
}

With 5 figures

\author{
Michael S. Engel and Holger H. Dathe
}

On the $10^{\text {th }}$ of May 2004 Palaearctic melittology and historical research in entomology lost one of its most important students in the passing of Dr. Donald Burton Baker. The following account is taken from autobiographical notes shared by Donald with the authors as well as from letters from and personal reminisces or discussions with Donald and Madge Baker.

Donald was the eldest son of Philip Buckingham Baker (1845-1931) and Agnes Anderson Russell (1884-1966). He was born in Putney, London on 2 June 1922. Donald's father was already 77 by the time of Donald's birth and the generation gap between his father and grandfather was similarly impressive (his grandfather, Richard George Baker, was born in 1789, matriculated at Trinity College, Oxford in 1807, and called to the Bar in 1813. He passed away in 1864.). This impressive genealogy and broad generational divide perhaps accounted for Donald's deep interest in history and genealogy. Like his father and kin, such as the Victorian explorer Sir Richard F. Burton (1821-1890; Donald's father's first cousin who lived in the home of Donald's grandfather and for whom he received his middle name), Donald held an abiding interest in Asia and the Near East, and exhibited a rare talent with languages. His father was president of the Delhi \& London Bank and purportedly had a framed case of Indian butterflies on his office wall, suggesting that the passion for natural history was similarly genetic.

Shortly following Donald's birth the family moved to Harlow, Essex. At the time Harlow was a small village surrounded by farmland and Donald grew up riding in these fields and collecting bird eggs and butterflies, encouraged in the latter respect by a local doctor, Dr. Day, who gave Donald his first book on butterflies and some setting boards. In addition, Day entrusted Donald, at the age of about 8 or 9 , with a cyanide bottle with turned boxwood stopper. Around the same age, Donald infuriated his governess by telling her that what she gave him as "a fossil seed-pod from India" was in fact a fossil sea-urchin and probably of English origin. The late Maurice Burton, who worked at the Natural History Museum on Porifera, also encouraged Donald's interests in nature, giving him some of his natural history books and also specimens (especially fossils). At about the age of 10 Donald was first given his "behind the scenes" experience at the Natural History Museum, viewing what he described as "not-very-interesting" sponge spicules through a microscope. Despite the less than enthralling subject matter, Donald's interest continued to grow and eventually enlarged to include the Coleoptera and Hymenoptera. School holidays afforded the young Donald opportunities to visit entomological dealers such as W. H. Janson \& Son in Great Russell Street (opposite of the British Museum) and Watkins \& Doncaster in the Strand, where pocket money could be spent to acquire coleopteran trophies from all over the world - including types of J. O. Westwood and specimens of A. R. Wallace from the Aru Islands and the Moluccas. 


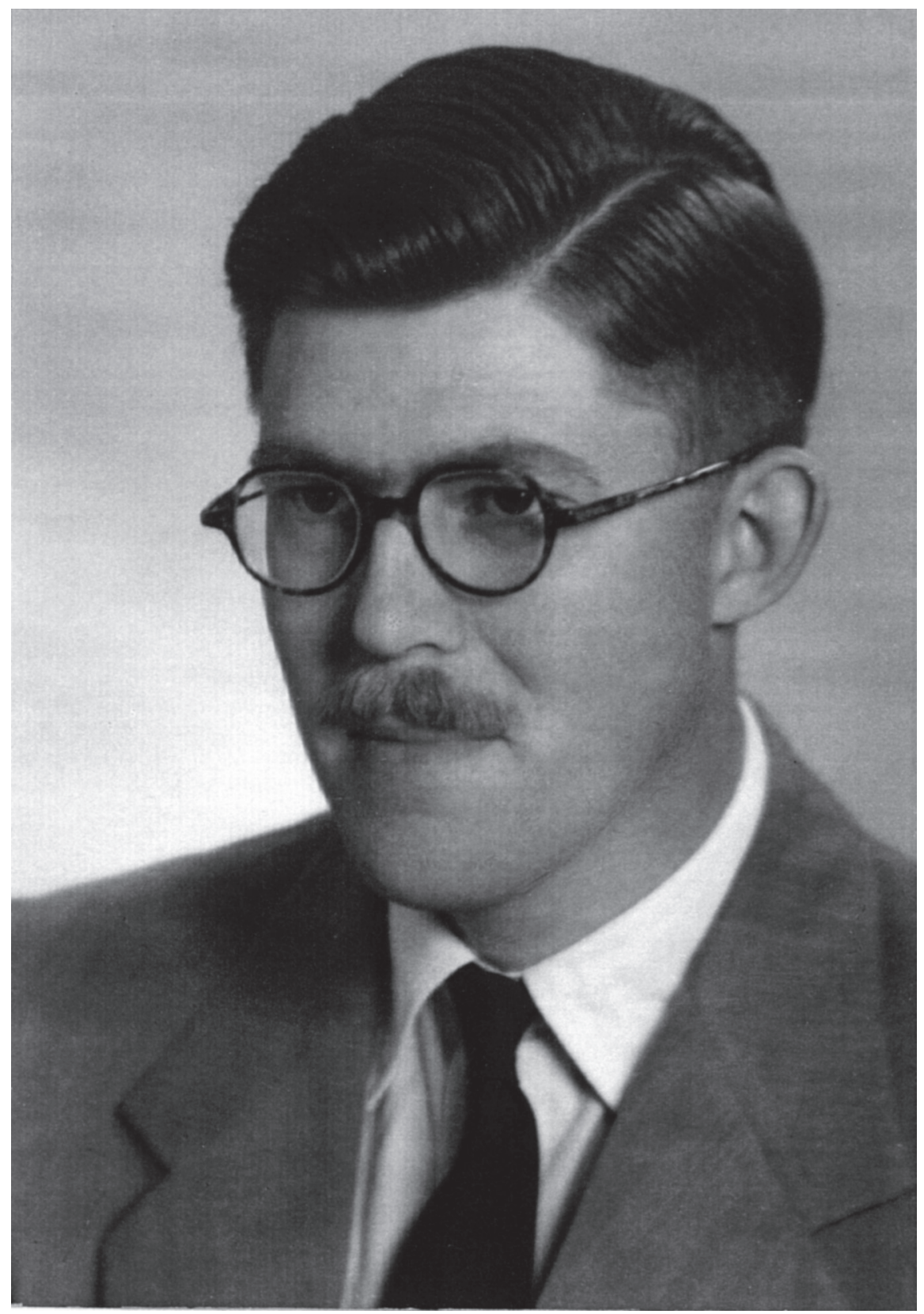

Fig. 1: Donald Burton Baker as he appeared in 1953 at the time of his marriage to Madge.

In 1933 his mother moved the family to Cheam, Surrey. Donald was educated at first privately, then, while the family remained at Harlow, as a day boy at a local boarding school, Harlow College, Essex, and finally, after their move to Surrey, he went up to King's College, University of London (following the outbreak of war King's College was evacuated to Bristol). In April of 1942, having been unable to obtain deferment of call-up to enable him to complete his B. Sc. in zoology 
and botany, Donald reported for military service. After the usual basic training and subsequent progress through Pre-OCTU and OCTU (Officer Cadet Training Units) Donald was commissioned in 1944 into the Indian Army but later was transferred to the British Service. Donald was eligible to leave military service in 1947 . However, he concluded that there would be no opportunities for museum employment in entomology and applied for commission into the Regular Army while still stationed in Italy. His reasoning, which proved to be amazingly sound, was that he would be afforded the opportunity to travel and collect all the while engaging in interesting "official" work. Donald went before a Regular Army Commissions Board at Udine and following several days of written and practical examinations was duly accepted.

It was during his assignment in Italy that Donald made the conversion to bees, a moment best related in his own words, "The English bee fauna is not a very rich or particularly interesting one, and for some time the Coleoptera remained my principal interest. Conversion was immediate and complete. A morning's collecting on a hillside in the Appenines, outside Benevento, alive with Anthophora, Eucera, Habropoda, and others unfamiliar, opened my eyes to the wealth and diversity of the Mediterranean bee fauna, and from that date, 11 March 1946, bees became a dominating interest in my life." [BAKER, in litt. to author 2002]

The field of systematic melittology could not have been more blessed by this conversion. Donald collected wherever he was stationed and whenever opportunities arose. Among the numerous locales (visited either as a resident or for shorter periods) were various central and southern European countries, particularly Spain, Italy, and Yugoslavia; Cyprus; Egypt; Lebanon; Iran; Malaysia; Philippines; and the United States. His collection continued to grow throughout his professional life and eventually included important material from regions such as Afghanistan, the United Arab Emirates, Oman, Saudi Arabia, and many others otherwise underrepresented in museums. By the time of his death his collection amounted to $c a .3500$ species represented by $c a$. 60,000 specimens.

Donald spent his career in Government Service (1944-1977) in the Army and on secondment to the Foreign Office and Government Communications Headquarters. As parts of his training he attended the School of Oriental and African Studies, University of London (1951-1953), College of Aeronautics, Cranfield (1959), U.S. Army Ordnance School (1961), among other specialist courses in the U.K. and abroad. As Donald noted (in litt., 2002), "Details of this period are of little interest entomologically, although various appointments did of course offer opportunities for collecting in places that I might otherwise never have been able to visit - and some that I might have preferred not to visit."

On 30 May 1952 Donald married Marjorie (Madge) Winifred Brockbank (née Adams) and, as he himself noted, “... lived happily ever afterwards". Madge proved to be the ideal companion to Donald as she was intelligent, energetic, and adventurous. Together they collected in all of the places where Donald was stationed during the remainder of his government service (except for his brief time in the United States). Madge was not only a good collector, who often captured species that he missed, but also an excellent driver (as Donald gave up driving after an automobile accident) and a constant source of support and encouragement. The happy couple had one son, Piers H. B. Baker, who, like his father, is uncommonly charming and learned, and who also proved to be a talented collector.

Donald always described himself as an amateur entomologist, since he never held a formal, academic appointment. However, as his publications demonstrate (vide infra), he was an uncommonly professional "amateur" and his contributions to systematic melittology are among the most 


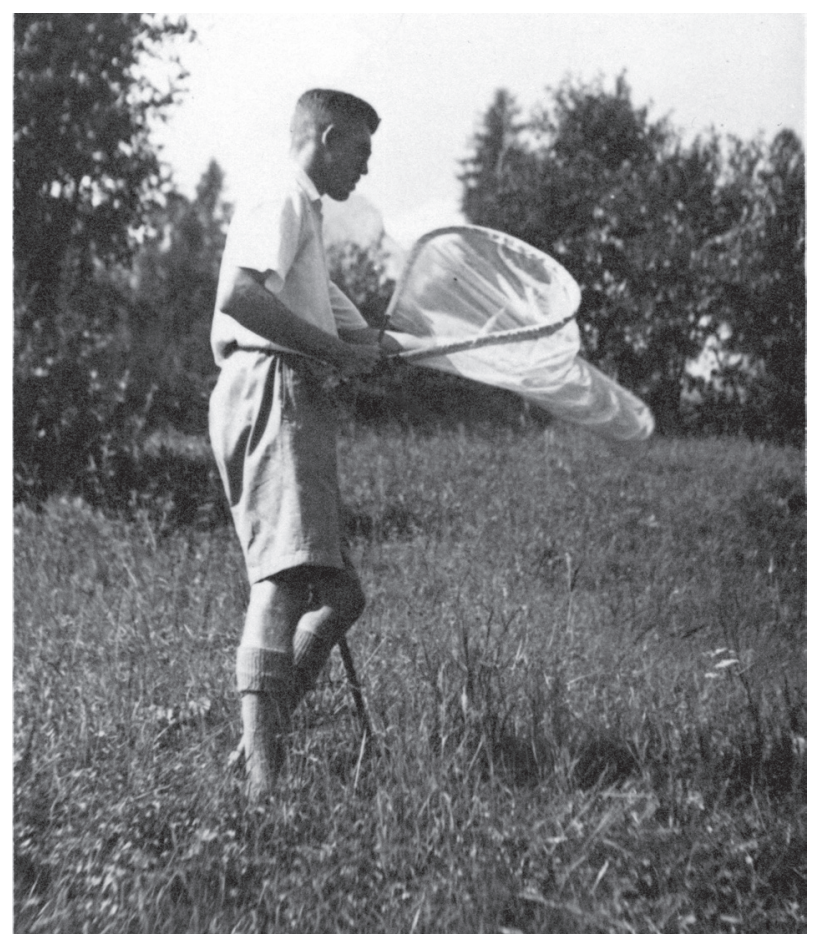

Fig. 2: Baker collecting insects in the Italian Alps (Dolomites), 17 August 1947.

valuable. Moreover, he worked in an effectively professional manner in or with major museums all over the world and communicated regularly with luminaries of our science such as Prof. F. Silvestri, Dr. A. Giordani-Soika, Dr. M. Fischer, Prof. Dr. K.-H. Rechinger, Dr. K. V. Krombein, Prof. Dr. C. D. Michener, Prof. V. V. Popov, Prof. Dr. H. Priesner, Dr. B. Pittioni. As in systematic entomology, his interests and expertise were broad. Donald was an authority in such far-reaching areas as hellenistic numismatics (particularly the tetradrachms of Alexander's eastern mints and the coinage of Ptolemy I), early Islamic ceramics (especially those of Iran, about which he frequently lectured), Oriental languages and cultures (particularly the languages of the Near East), and the history of natural history (especially little-known $19^{\text {th }}$ century explores such as John Keast Lord). He was made a Fellow or Member of the Royal Entomological Society (FRES, 1943), the Linnean Society of London (FLR), the Royal Geographical Society (FRGS), the British Entomological \& Natural History Society (1939), the Institute of Biology (MIBiol), the Commonwealth Institute of Biology (CBiol), the British Institute of Persian Studies, the Society for Afghan Studies, the Society for South Asian Studies, and the Society for the History of Natural History. Donald was truly one of the last great polyhistors!

After retirement from HMS, Donald undertook voluntary curatorial work at the Natural History Museum, London (1977-1984) and eventually matriculated at St. John's College, Oxford for postgraduate studies (1984-1993), completing his D. Phil. on the type material and history of the British hymenopteran systematist Frederick Smith. His research was done in large part from his home study, although he was able to work in the collections of the University Museum, Oxford and the Natural History Museum, London. After completing he entered a remarkably productive period, producing each year numerous important works on the taxonomy of bees and the history of entomology and natural history science. The only deterrents were increasing age, ill health, and mild deafness. 


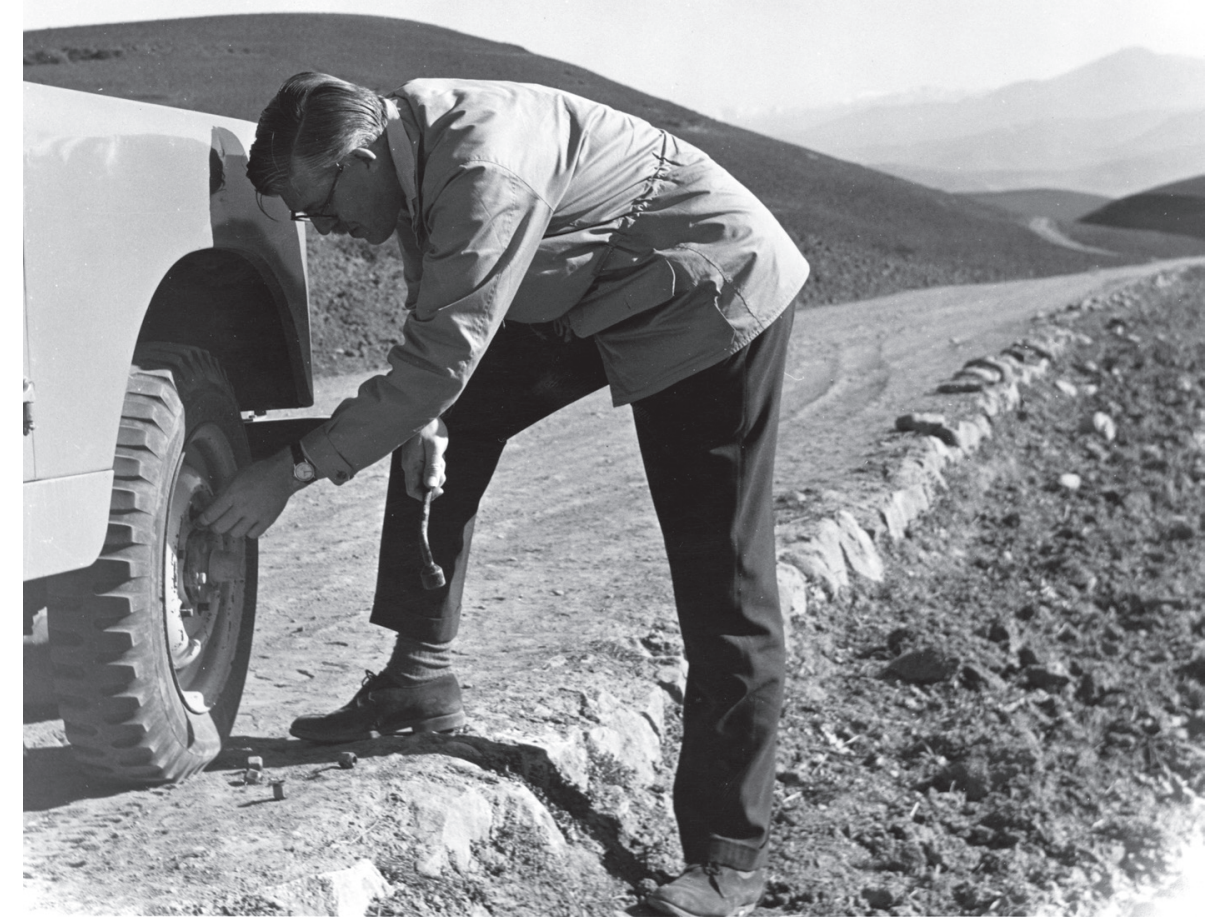

Fig. 3: Baker exploring Iran (mid-1960s).

Donald's scientific work is highly unusual in many respects, and has its own distinctive character. He discusses mainly problems which hardly anybody had previously investigated, because few others could afford to do so. Donald himself must have become aware, that for the elucidation of many taxonomic problems, a stock of reliable facts is essential, gleaned from careful interpretation of such diverse disciplines as history, biogeography, bibliography, linguistics, and geography. $\mathrm{He}$ also apparently recognized that his personal profile, education, and personal experiences would be ideal for solving such problems. Few other zoologists, whether in the field or in a museum, have been lucky to acquire such a usefully diverse range of skills. But he also shared the same basic motivation of us all - the general, human compulsion to collect, identify, and classify - accompanied by an acutely inquiring love of nature. Donald Baker was certainly a lucky addition to the entomological community, although the significance of his work does not yet really seem to have been fully appreciated.

Here it is unfortunately not possible to present a full appreciation of Donald's scientific work - his contributions to entomology and other sciences have too many layers of significance. His chosen themes involve an astonishing range of taxa and variety of specific aspects of these which are investigated. Despite this, his work does not appear haphazard or opportunistic. A pivotal event in his life was certainly the aforementioned completion of his doctoral thesis [The type material of the nominal species of exotic bees described by Frederick Smith (Hymenoptera, Apoidea), Oxford 1993], which had led him, both in scope and methodology, into the deeps of taxonomic working. To write this work, he had to analyze a vast stock of relevant information dating back through the $19^{\text {th }}$ Century. Frederick Smith published his works on Hymenoptera between about 1840 and 1880 and was for many years the representative at the British Museum in our discipline. 


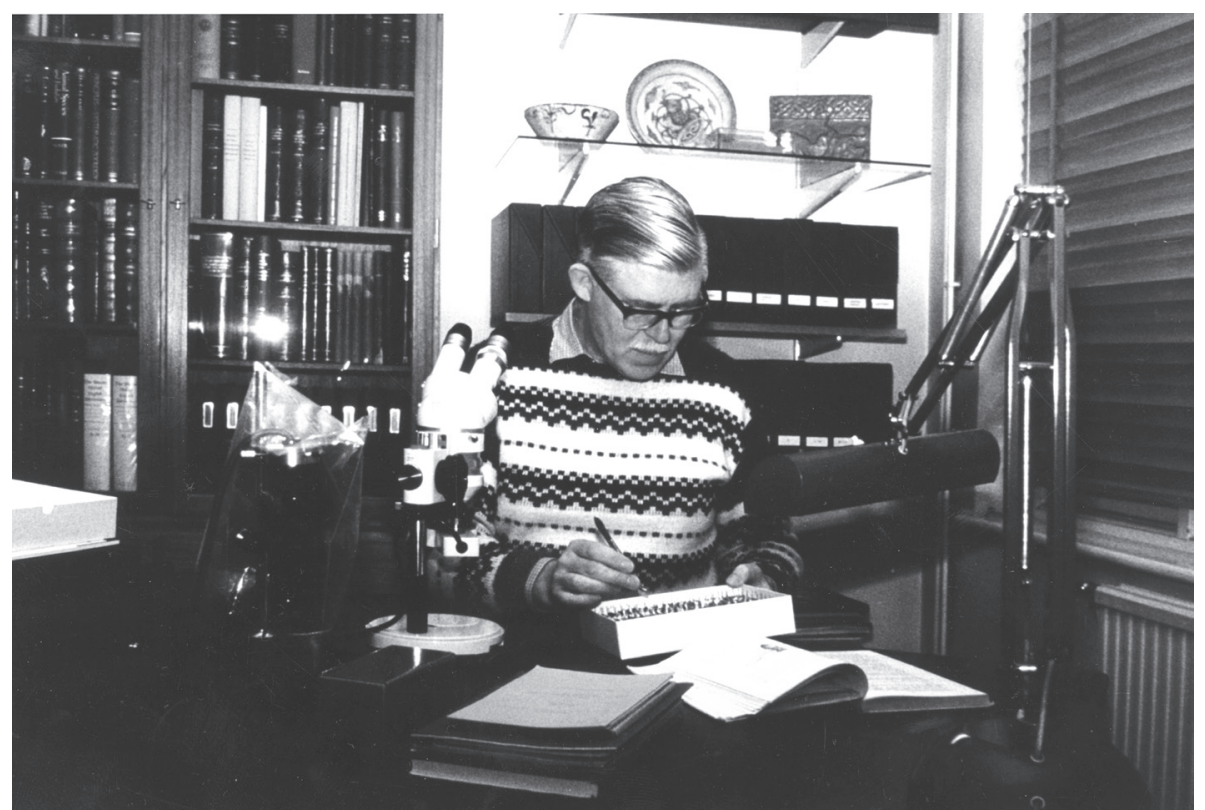

Fig. 4: Baker in his home study at Cheam, Surrey (early 1980s).

Donald obtained his doctoral degree cum laude, at Oxford University. As his then supervisor, Prof. Cornelis van Achterberg (Leiden, NL), said, "he did it very well, in his usual meticulous way, but the result was positive and we were soon ready with our conclusion". It was already a singular achievement, at the age of 71, to successfully answer the challenge of tackling such difficult venture. After this, the near explosion of work by Donald is further evidence of his exceptionally great energy. In the last ten years of his life, he published over 50 manuscripts! As early as 1994 six publications appeared and in each of the following years several important papers were produced each year. The high point was reached in 1996, with 12 articles, and even until recently valuable manuscripts from his legacy have been completed and published. The works themselves document the extensive knowledge acquired during many years of practice in collection and identification. Donald visited many regions, through his work in the diplomatic service, which often were completely unmapped areas of melittology. Especially noteworthy collections came from the Oriental Region, including the Indian and Malayan Provinces, from Thailand, Sulawesi, and Kalimantan. In the current "Darwin Year", much has been said of Alfred Russell Wallace; whose fundamental contributions to the zoogeography of insects of the Malay Archipelago had already been highlighted by Donald in 1995. He collected valuable material in Afghanistan, Iran, and the Arab States, and it is heartening that much of this has been published upon.

In his writings, a certain concentration of effort on the family Apidae is evident, but Donald was not a complete specialist. He published on distributional, nomenclatorial, and taxonomic problems in nearly all other bee families (Colletidae, Andrenidae, Halictidae, Melittidae, and Megachilidae). His works on Palaearctic and Oriental species of the genera Systropha (1996) and Pseudapis / Nomiapis (2002) have become classics. The last is one of his last great works, including a cladistic analysis of characters, which clearly illustrates Donald's openness for use of modern phylogenetic methods in systematic work. His photographic documentation is legendary, evidence of skill and engagement. These publications have been an extraordinary enrichment of our knowledge on the bionomics and diversity of the bees. 


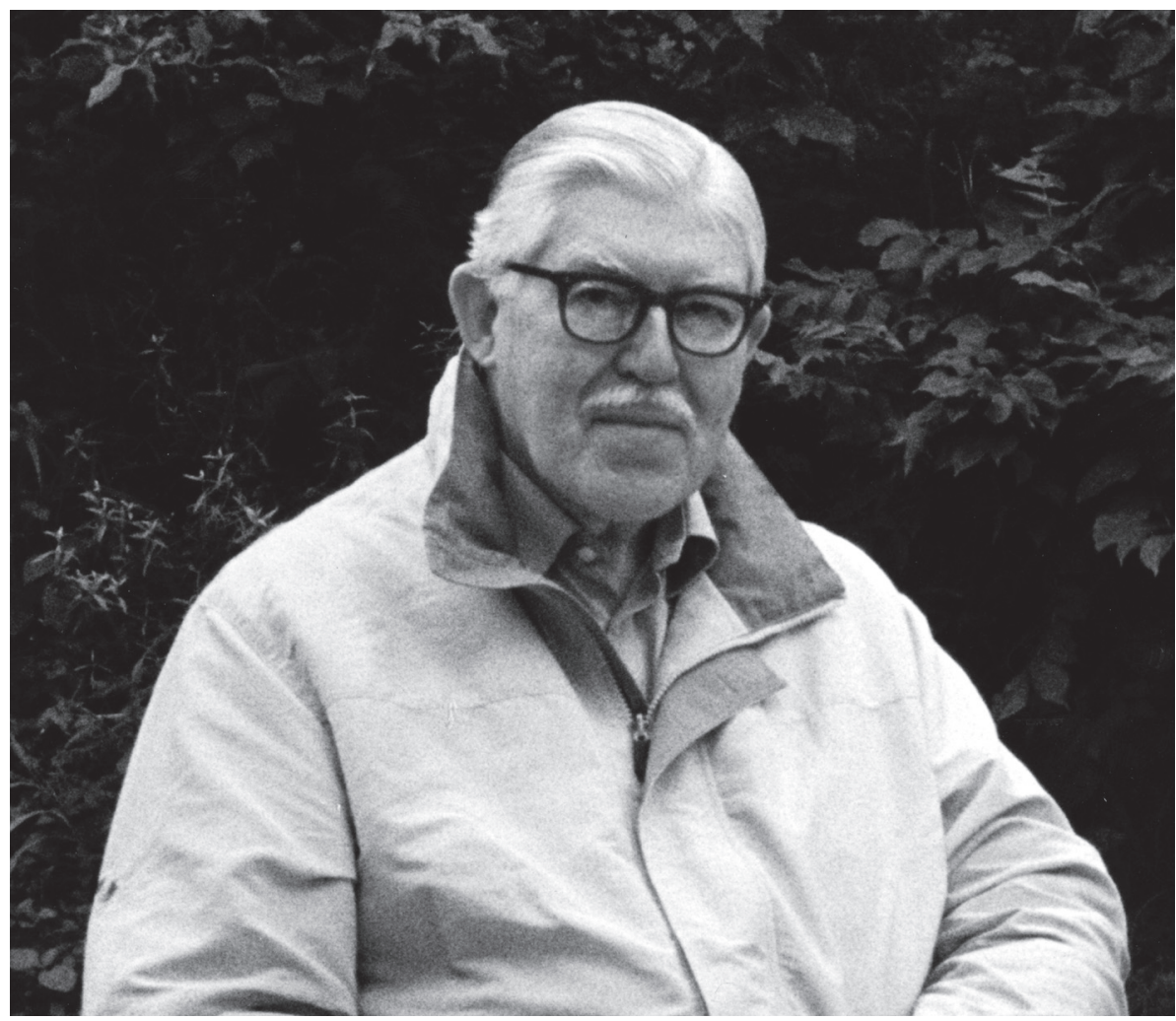

Fig. 5: Baker in Vienna (2002).

Donald's friends are glad also for other reasons, that he finally recorded his knowledge in writing. Until the early 1990's, he was a much feared critic of work on melittology. He examined the literature minutely, with much attention given to the accuracy of language, as well as geographical, historic, nomenclatorial, and other details, which admittedly occasionally presented a problem (or were unimportant) for many of us. Especially annoying to the recipient of his pointedly formulated critiques, was that he was nearly always right. Not everyone found this forced confrontation with one's mistakes helpful, but at least one was made more aware of pitfalls to avoid in the next work. It is certainly not possible to measure by how much Donald in this way indirectly contributed to an increase in quality of melittological publications, but without doubt the effect was significant. He knew the most dangerous hazards of the subject, and it has to be reckoned highly to him, that he did not satisfy himself with the role of critic, but also himself wrote contributions fundamental to clarifying many problems. We are indebted to him for example for thoroughly researched data on the works of early authors, including Lepeletier De SAINT FArgeau, Latreille, Kirby, Spinola, Costa, Pérez, Schmiedeknecht, Alfken, and many others. He was not afraid to bring order even to the chaos of GISTEL - no mean accomplishment. Unforgotten (particularly by some editors) is his meticulous attention to the transcription of non-Latin alphabet languages, for example of collecting localities. However, one could always be sure about the serious intent and careful research on which he based his reasoning. His achievements are unique in our metier, and whilst one may not accept Donald's results in every case, his analyses must never be ignored. 
Early in 2001 Donald informed the senior author of his wish that he should prepare to receive Donald's collection in parts. It was Donald's desire to see his collection transferred to the University of Kansas Natural History Museum and designated as the Donald and Madge Baker Collection. There it would, along with the collection developed principally by Prof. Dr. Charles D. Michener, the senior author, and their students, serve as a unique research resource for the study of melittological systematics. The monumental task of moving the collection was achieved in three stages in 2003 and 2004, the last following Donald's death. It had been hoped that he and Madge might someday be capable of the long journey from Ewell to Lawrence to see the collection in its new home. It is deeply regretted that this never came to pass. The entire Division of Entomology at the University of Kansas moved in 2006 to a new facility with a single, large, climate-controlled, clean collection room that is to be maintained pesticide free for all parts of the Division's holdings (rather than the segregation of different taxonomic groups in separate rooms as previously housed in Snow Hall). As Donald's original wooden cases were insufficient to prevent invasion by museum pests in the absence of some chemical deterrent, the collection was transferred into standard drawers and cases for safe housing (through the detailed and diligent assistance of Mr. Ismael A. Hinojosa-Díaz). Each specimen is labeled as being a part of the Donald and Madge Baker Collection and is incorporated into the aisles of the bee collection.

As a final, personal note, we mourn the loss of an esteemed colleague but also that of a friend. Donald and the authors shared similar interests, corresponding regularly from about 1998 until his death. They also had the pleasure to visit Donald and Madge at their home and to work with Donald in the study several times. These numerous visits were among the most illuminating moments in the senior author's brief career. Although considered gruff by some (obviously those who did not know him), Donald was in actuality a warm individual, sharing of his time, his expansive knowledge, and his collection. Donald was a charming and proper man, typical for someone of his learning, experience, and background, who towered above others owing to his great height. He had an insatiable curiosity and massive thirst for intellectual stimulation. Some of the senior author's most wonderful memories will be from his last visit to see the Bakers in January 2004. It was during that trip that Donald and Madge shared some of their adventures while living in Iran, brought out the antique rifle of Sir Richard Burton, and Donald related many personal remembrances from his childhood, adolescence, courtship of Madge, service in World War II, and, of course, always his science.

To this day we continue to mourn the palpable absence of our friend, mentor, and colleague. Our hearts and minds are eased by our fond memories and by the legacy of scholarship and the incalculably valuable research material which will illuminate future generations. Oh, but what we would not give for one last afternoon, in the study, shoulder to shoulder with our friend looking over a tray of bees from far off times and places. May he rest in peace.

"Sometimes, when one person is absent, the whole world seems depopulated." - Alphonse de Lamartine (1790-1869), Méditations Poétiques (1820) 


\section{Eponyms}

Andrenidae: Panurginae

Camptopoeum bakeri Rozen, 1988: 7.

Colletidae: Hylaeinae

Hylaeus donbakeri Dathe, 1995: 160.

Halictidae: Halictinae

Lasioglossum (Ctenonomia) bakeri PAuly, 2001: 267.

Megachilidae: Megachilinae

Eoanthidium bakerorum ENGEL, 2004: 2.

\section{References}

Dathe, H. H. 1995: Studien zur Systematik und Taxonomie der Gattung Hylaeus F. (Apidae, Colletinae). 2. Klärung und Neubeschreibung von Arten arabischer Länder. - Beiträge zur Entomologie 45 (1): 155-174.

ENGEL, M. S. 2004: A new species of the bee genus Eoanthidium with extraordinary male femoral organs from the Arabian Peninsula (Hymenoptera: Megachilidae). - Scientific Papers, Natural History Museum, University of Kansas 34: 1-6.

O’Toole, C. 2006: Obituary: Donald Burton Baker (1922-2004). - Entomologist's Monthly Magazine 142 (1706-1708): 177-183.

Pauly, A. 2001: Lasioglossum (Ctenonomia) bakeri, espèce nouvelle de Bornéo (Hymenoptera: Halictidae). - Bulletin de l'Institut Royal des Sciences Naturelles de Belgique, Entomologie 71: 267-269.

Rozen, J. G., Jr. 1988: Ecology, behavior, and mature larva of a new species of the Old World bee genus Camptopoeum (Andrenidae: Panurginae). - American Museum Novitates 2925: 1-12.

\section{Addresses of the authors:}

Prof. Dr. Michael S. ENGEL

Division of Entomology (Paleoentomology)

Natural History Museum

1501 Crestline Drive - Suite 140

University of Kansas

Lawrence, Kansas 66049-2811, USA
Prof. Dr. Holger H. Dathe

Senckenberg Deutsches Entomologisches Institut

Eberswalder Straße 90

15374 Müncheberg

Deutschland 


\section{Appendix 1}

\section{Publications of Donald B. Baker}

Note that the listing in O'Toole (2006) is missing a few papers and lists some incorrect titles, and is accordingly updated here. In addition, some articles listed therein as authored by BAKER are incorrect. Petitioners to the ICZN, for example, are not the authors of the Opinions rendered by the Commission but only of their initial petition (e.g., Opinion 1853 of the ICZN is erroneously attributed to BAKER). Such minor corrections are provided in the following list.

1. Baker, D. B. 1965: Two bees new to Britain (Hym., Apoidea). - Entomologist's Monthly Magazine 100 (1206-1207): 279-286. [Publication date: 14 September 1965]

2. Baker, D. B. 1969: Flying earwigs. - Entomologist 102 (1278 Nov.): 268. [Publication date: 4 November 1969 - unauthorized publication of private communication]

3. Baker, D. B. 1971: A new Pasitomachthes from Rhodesia (Hymenoptera, Apoidea). - Novos Taxa Entomologicos 98 (1): 1-8. [Publication date: September 1971]

4. Baker, D. B. 1971 [1972]: A new Tarsalia (Hym., Apoidea) from southern India. - Entomologist's Monthly Magazine 107 (1289-1291): 246-248. [Publication date: 9 June 1972]

5. Baker, D. B. 1972: A revision of the genus Plesiopanurgus CAmeron, with notes on some Arabian and African Panurginae (Hymenoptera: Apoidea). - Journal of Entomology, Series B, Taxonomy and Systematics 41 (1): 35-43. [Publication date: 14 July 1972]

6. Baker, D. B. 1974: Eupetersia, a genus of parasitic halictine bees (Hym., Apoidea) new to the Oriental Region. - Entomologist's Monthly Magazine 110 (1316-1318): 59-63. [Publication date: 16 December 1974]

7. Baker, D. B. 1975: Two genera of nomadine bees new to India (Hym., Apoidea). - Entomologist's Monthly Magazine 110 (1325-1327): 237-240. [Publication date: 22 December 1975]

8. Baker, D. B. 1978: Changes of name affecting Apoidea (Hym.) on the British list. - Entomologist's Monthly Magazine 113 (1356-1359): 137-138. [Publication date: 11 September 1978]

9. Baker, D. B. 1994: Type material in the University Museum, Oxford, of bees described by Comte Amédée Lepeletier de Saint-Fargeau and Pierre André Latreille (Hymenoptera: Apoidea). - Journal of Natural History 28 (5): 1189-1204. [Publication date: 22 September 1994]

10. Baker, D. B. 1994: The date of the Hymenoptera section of the Exploration scientifique de l'Algérie. - Archives of Natural History 21 (3): 345-350. [Publication date: October 1994]

11. Baker, D. B. 1994: The dates of the Hymenoptera sections of Costa's Fauna del Regno di Napoli. - Archives of Natural History 21 (3): 351-356. [Publication date: October 1994]

12. Baker, D. B. 1994: On the nomenclature of two sibling species of the Andrena tibialis (Kirby, 1802) group (Hymenoptera, Apoidea). - Entomologist's Gazette 45 (4): 281-290. [Publication date: 31 October 1994] 
13. Baker, D. B. 1994: The exotic bees described in William Kirby's "Monographia Apum Angliae” (Insecta: Hymenoptera: Apoidea). - Reichenbachia 30 (29): 177-179. [Publication date: 25 November 1994]

14. Baker, D. B. 1994: A new genus of nomadine bees from North Africa (Hymenoptera: Apoidea, Anthophoridae). - Tijdschrift voor Entomologie 137 (2): 155-159. [Publication date: 15 December 1994]

15. Baker, D. B. 1995: A new Malayan Andrena (Hymenoptera, Apoidea). - Deutsche Entomologische Zeitschrift 42 (1): 67-69. [Publication date: 3 March 1995]

16. Baker, D. B. 1995: Case 2884. Xerammobates Popov, 1951 (Insecta, Hymenoptera): Proposed designation of Ammobates (Xerammobates) oxianus Popov, 1951 as the type species. - Bulletin of Zoological Nomenclature 52 (2): 157-158. [Publication date: 30 June 1995; Resolved by the ICZN in: Opinion 1853. Xerammobates Popov, 1951 (Insecta, Hymenoptera); Ammobates oxianus Popov, 1951, designated as the type species. - Bulletin of Zoological Nomenclature 53 (3): 220. (Published 30 September 1996)]

17. BaKer, D. B. 1995: The nomenclature of Japanese Colletes LATreille (Hymenoptera: Colletidae) - a correction. - Entomologist's Gazette 46 (3): 194. [Publication date: 21 August 1995]

18. BaKer, D. B. 1995: The provenance of the Hymenoptera collected in Iran by Don Manuel Martinez de la Escalera. - Entomologist's Gazette 46 (4): 279-282. [Publication date: 20 October 1995]

19. Baker, D. B. 1995: A review of the Asian species of the genus Euaspis Gerstäcker (Hymenoptera: Apoidea: Megachilidae). - Zoologische Mededelingen 69 (22): 281-302. [Publication date: 29 December 1995]

20. Baker, D. B. 1996: On a collection of Bombus and Psithyrus principally from Sutherland, with notes on the nomenclature or status of three species (Hymenoptera, Apoidea). - British Journal of Entomology and Natural History 9 (1): 7-19. [Publication date: January 1996]

21. BaKer, D. B. 1996: Capital letters for English names. - British Journal of Entomology and Natural History 9 (1): 61-62. [Publication date: January 1996]

22. Baker, D. B. 1996: Hymenoptera collections of Boyer de Fonscolombe: Apoidea in the University Museum, Oxford. - Journal of Natural History 30 (4): 537-550. [Publication date: April 1996]

23. BaKer, D. B. 1996: An annotated list of the nominal species assigned to the genus Afrostelis Cockerell (Hymenoptera, Apoidea, Megachilidae). - Deutsche Entomologische Zeitschrift 43 (1): 155-157. [Publication date: April 1996]

24. BAKer, D. B. 1996: On a collection of humble-bees from northern Iran (Hymenoptera: Apoidea, Bombinae). - Beiträge zur Entomologie 46 (1): 109-132. [Publication date: 15 May 1996]

25. Baker, D. B. 1996: Pfeiffer, Wallace, Allen and Smith: The discovery of the Hymenoptera of the Malay Archipelago. - Archives of Natural History 23 (2): 153-200. [Publication date: June 1996]

26. Baker, D. B. 1996: The dates of Schmiedeknecht's Apidae Europaeae. - Archives of Natural History 23 (2): 295-298. [Publication date: June 1996] 
27. BakeR, D. B. 1996: Priorities of publication for some nineteenth-century works describing new taxa of Hymenoptera, principally Apoidea. - Archives of Natural History 23 (2): 299-302. [Publication date: June 1996]

28. Baker, D. B. 1996: The identity of Apis zonata Linnaeus, 1758 (Insecta: Hymenoptera: Apoidea: Anthophoridae). - Reichenbachia 31 (36): 203-206. [Publication date: 2 September 1996]

29. Baker, D. B. 1996: Notes on some Palaearctic and Oriental Systropha, with descriptions of new species and a key to the species (Hymenoptera: Apoidea: Halictidae). - Journal of Natural History 30 (10): 1527-1547. [Publication date: October 1996]

30. BaKer, D. B. 1996: Two little-known nineteenth century collectors: Dr. Thomas Dowler and John Keast Lord, Esq., F.Z.S. - Archives of Natural History 23 (3): 385-398. [Publication date: October 1996]

31. Baker, D. B. 1996: The dates of publication of Westwood's Arcana entomologica and the 'missing' tropical articles. - Archives of Natural History 23 (3): 437-443. [Publication date: October 1996]

32. BaKer, D. B. 1997: Notes on Pithitis species from the Indian subcontinent (Insecta: Hymenoptera: Apoidea). - Reichenbachia 32 (14): 85-90. [Publication date: 30 July 1997]

33. Baker, D. B. 1997: A new species of Plesiopanurgus Cameron from Morocco (Hymenoptera: Apoidea, Andrenidae). - Entomologist's Gazette 48 (3): 199-203. [Publication date: 31 July 1997]

34. Baker, D. B. 1997: The Apoidea described by Johannes Nepomuk Franz Xaver Gistel (Insecta: Hymenoptera). - Beiträge zur Entomologie 47 (2): 327-336. [Publication date: 4 August 1997]

35. Baker, D. B. 1997: New Melectini from western China (Hymenoptera: Apoidea, Anthophoridae). - Entomologist's Gazette 48 (4): 245-256. [Publication date: 31 October 1997]

36. Baker, D. B. 1997: C. G. Ehrenberg and W. F. Hemprich's travels, 1820-1825, and the Insecta of the Symbolae Physicae. - Deutsche Entomologische Zeitschrift 44 (2): 165-202. [Publication date: 18 December 1997]

37. BaKer, D. B. 1998: The dates of publication of Perez's Espèces nouvelles de Melliferes, 19021903. - Entomologist's Gazette 49 (1): 67-68. [Publication date: 30 January 1998]

38. Baker, D. B. 1998: The Hymenoptera collections of William Edward Shuckard and the dispersal of his type material. - Beiträge zur Entomologie 48 (1): 157-174. [Publication date: 31 March 1998]

39. BaKer, D. B. 1998: Taxonomic and phylogenetic problems in Old World eucerine bees, with special reference to the genus Tarsalia Morawitz, 1895 (Hymenoptera: Apoidea: Anthophoridae). - Journal of Natural History 32 (6): 823-860. [Publication date: June 1998]

40. Baker, D. B. 1998: On some cleptoparasitic bees of the genera Aglaoapis Cameron, 1901, and Paradioxys Mocsáry, 1894 (Hymenoptera: Apoidea, Megachilidae), with the description of a remarkable new species. - Entomologist's Gazette 49 (3): 203-208. [Publication date: 31 July 1998]

41. BaKer, D. B. 1998: Validity of Gistel names in the Insecta. - Beiträge zur Entomologie 48 (2): 539. [Publication date: 5 October 1998] 
42. Baker, D. B. 1999: The Faune Ligustice Fragmenta of Massimiliano Spinola (1805). - Beiträge zur Entomologie 49 (1): 141-146. [Publication date: 6 April 1999]

43. Baker, D. B. 1999: The localities of I. A. Scopoli’s Entomologia Carniolica (1763). - Entomologist's Gazette 50 (3): 188-198. [Publication date: July 1999]

44. BaKer, D. B. 1999: J.D. Alfken's publications on the Hymenoptera. - Beiträge zur Entomologie 49 (2): 463-483. [Publication date: 13 September 1999]

45. BAKer, D. B. 1999: The nomenclature of European Colletes (Hymenoptera, Apoidea) - a correction; The dates of the Apoidea of Frey-Gessner's Hymenoptera Helvetiae (1898-1912) and Hyménoptères du Valais (1902-1916) (Hymenoptera). - Beiträge zur Entomologie 49 (2): 485-488. [Publication date: 13 September 1999; Errata - Beiträge zur Entomologie 50 (1): 236]

46. BaKer, D. B. 1999: On new stelidine bees from S. W. Asia and N. W. Africa, with a list of the Old-World taxa assigned to the genus Stelis PAnzer, 1806 (Hymenoptera, Apoidea, Megachilidae). - Deutsche Entomologische Zeitschrift 46 (2): 231-242. [Publication date: 30 November 1999]

47. Baker, D. B. 2000: Sutton Natural History Society. - Newsletter of the Society for the History of Natural History 66: 11. [Publication date: January 2000]

48. Baker, D. B. 2000: Andrena pilipes Fabricius, 1781: Designation of neotype (Insecta: Hymenoptera: Apoidea: Andrenidae). - Reichenbachia 33 (55): 421-425. [Publication date: 30 March 2000]

49. Baker, D. B. 2001: Alfred Russel Wallace's record of his consignments to Samuel Stevens, 1854-1861. - Zoologische Mededelingen 75 (16): 251-341. [Publication date: 24 December 2001]

50. Baker, D. B. 2002: John Keast Lord: Materials for a Life. - Pp. [i]-viii, [1]-65. - Leiden: Backhuys Publishers. [Publication date: 13 March 2002]

51. BaKer, D. B. 2002: Halictus tectonae Narendran \& JobiraJ, 2000, nomen dubium (Hymenoptera, Apoidea, Halictidae): The need for censorship in taxonomy. - Antenna 26 (2): 76-78. [Publication date: April 2002]

52. BaKer, D. B. 2002: On the identity of Ceratina (Ceratinidia) hieroglyphica SMITH (Insecta: Hymenoptera: Apoidea: Anthophoridae). - Reichenbachia 34 (44): 357-373. [Publication date: 10 June 2002]

53. BAKER, D. B. 2002: A provisional, annotated, list of the nominal taxa assigned to the genus Dasypoda Latreille, 1802, with the description of an additional species (Hymenoptera, Apoidea, Melittidae). - Deutsche Entomologische Zeitschrift 49 (1): 89-103. [Publication date: 25 June 2002]

54. Baker, D. B. 2002: On Palaearctic and Oriental species of the genera Pseudapis W. F. Kirby, 1900, and Nomiapis Cockerell, 1919 (Hymenoptera, Halictidae, Nomiinae). - Beiträge zur Entomologie 52 (1): 1-83. [Publication date: 31 August 2002]

55. Baker, D. B. 2002: On Sulawesi Ceratina (Ceratinidia) (Hymenoptera, Apoidea, Anthophoridae). - Beiträge zur Entomologie 52 (2): 337-345. [Publication date: 16 December 2002]

56. Baker, D. B. 2003: Heinrich Friese (1860-1948): Type localities in the Caucasus. - Entomologist's Gazette 54 (1): 35-37. [Publication date: 31 January 2003] 
57. BAKer, D. B. 2003: Ulugombakia, a new eucerine bee from Malaya (Hymenoptera: Apoidea: Apidae). - Beiträge zur Entomologie 53 (1): 123-129. [Publication date: 31 July 2003]

58. BaKer, D. B. 2004: Hymenoptera collections from Qatar, the United Arab Emirates and Oman. - Beiträge zur Entomologie 54 (1): 97-105. [Publication date: 28 May 2004]

59. BaKer, D. B. 2004: Winkler, Wien: Die Geschichte eines entomologischen Handelshauses. - Entomologische Blätter für Biologie und Systematik der Käfer 100 (1): 9-12. [Publication date: 30 June 2004]

60. Baker, D. B. 2004: Type material of Hymenoptera described by O. I. Radoszkowsky in the Natural History Museum, London, and the localities of A. P. Fedtschenko's Reise in Turkestan. - Deutsche Entomologische Zeitschrift 51 (2): 231-252. [Publication date: 26 November 2004]

61. Baker, D. B. \& Engel, M. S. 2006: A new subgenus of Megachile from Borneo with arolia (Hymenoptera: Megachilidae). - American Museum Novitates 3505: 1-12. [Publication date: 12 January 2006]

62. Baker, D. B. 2006: A synonymical note in the bee genus Euaspis Gerstaecker, 1857 (Hym., Megachilidae). - Entomologist's Monthly Magazine 142 (1703-1705): 106. [Publication date: 28 April 2006]

63. Engel, M. S. \& Baker, D. B. 2006: A remarkable new leaf-cutter bee from Thailand (Hymenoptera: Megachilidae). - Beiträge zur Entomologie 56 (1): 69-74. [Publication date: 15 August 2006]

64. Engel, M. S. \& Baker, D. B. 2006: A new species of Tetralonia (Thygatina) from India, with notes on the Oriental fauna (Hymenoptera: Apidae). - American Museum Novitates 3527: 1-9. [Publication date: 8 September 2006]

65. Baker, D. B. \& Engel, M. S. 2007: A note on the nomenclature of two Coelioxys species (Hymenoptera: Megachilidae). - Entomologist's Gazette 58 (1): 59-62. [Publication date: January 2007]

\section{Dissertation}

D1. BaKer, D. B. 1993: The Type Material of the Nominal Species of Exotic Bees Described by Frederick Smith. - Pp. [i] + [i] -vi + 1-312, +14 pls. - Oxford: Ph. D. dissertation, Oxford University. [Michaelmas (Autumn) Term, 1993] 


\section{Appendix 2}

Taxa proposed by Donald B. Baker

(8 genus- and 34 species-group taxa)

The following list provides a complete catalogue of those taxa established by BAKER. The listing in O'Toole (2006) is missing some taxa proposed subsequent to the submission of his obituary while one epithet, Bombus laevis agricolae, was overlooked.

Andrenidae

Andrena (Malayapis) BAKER, 1995

Andrena (Malayapis) chrysochersonesus BAKER, 1995

Plesiopanurgus hanno BAKER, 1997

Plesiopanurgus ibex BAKER, 1972

Apidae

Aethammobates BAKER, 1994

Aethammobates prionogaster BAKER, 1994

Ammobates (Ammobates) chionospilus BAKER, 1975

Bombus laevis agricolae BAKER, 1996

Ceratina (Ceratinidia) alexandrae BAKER, 2002

Ceratina (Ceratinidia) carinifrons BAKER, 2002

Ceratina (Ceratinidia) bowringi BAKER, 2002

Ceratina (Ceratinidia) hieratica BAKER, 2002

Ceratina (Ceratinidia) demotica BAKER, 2002

Ceratina (Ceratinidia) coptica BAKER, 2002

Glazunovia BAKER, 1998

Melecta emodi BAKER, 1997

Morgania castanomelaena BAKER, 1975

Pasitomachthes argentatus BAKER, 1971

Pithitis vechti BAKER, 1997

Sinomelecta BAKER, 1997

Sinomelecta oreina BAKER, 1997

Tarsalia deccana BAKER, 1971 [1972]

Tarsalia strobilanthae BAKER, 1998

Tetralonia (Thygatina) macroceps ENGEL \& BAKER, 2006

Ulugombakia BAKER, 2003

Ulugombakia platytarsus BAKER, 2003 
Halictidae

Eupetersia (Nesoeupetersia) nathani BAKER, 1974

Nomiapis carcharodonta BAKER, 2002

Nomiapis kophenes BAKER, 2002

Pseudapis fayumensis BAKER, 2002

Pseudapis stenotarsus BAKER, 2002

Systropha androsthenes BAKER, 1996

Systropha diacantha BAKER, 1996

Megachilidae

Euaspis edentata BAKER, 1995

Euaspis lorenzae BAKER, 1995

Euaspis wegneri BAKER, 1995

Megachile (Aethomegachile) ENGEL \& BAKER, 2006

Megachile (Matangapis) BAKer \& ENGEL, 2006

Paradioxys ruyanensis BAKER, 1998

Stelis (Stelis) laverna BAKER, 1999

Xenostelis BAKER, 1999

Xenostelis polychroma BAKER, 1999

Melittidae

Dasypoda litigator BAKER, 2002 